\title{
Newcomer Experiences
}

We live in a very globalised world, and Canada is a country known for having open arms for newcomers and the myriad of beautiful cultures that come with them. With Canada's large population of immigrants and first generation Canadians, picture books are important artifacts that reflect newcomer narratives.

Working as mirrors for children who are new to Canada and as windows for children who are Canadian born, these picture books are a great way to discuss reasons for immigration, such as searching for a better life or escaping war zones. Older readers learning English might also appreciate the subject matter in these books as well as their simple vocabulary and sentence structures. In addition to these reasons for reading, this particular group of books also shares stories of courage as people move their entire lives from one country to another - and such courage can inspire us all.

While the theme of newcomer experiences is a powerful one, books on this topic published since 2017 are a small but increasing presence. Although this chapter is shorter than others in this volume, it includes some of the very best storytelling and illustration in our entire Canadian collection. In addition to titles specifically about newcomer journeys, a few books that resonate with feelings related to "being the new kid in town" are also included in this group.

Where not otherwise indicated, the name of the author(s) appears first under each title, and the illustrator last.

\section{My Friend \\ Elisa Amado \\ and Alfonso Ruano}

The narrator of this story is a young girl who has recently moved. While her journey is from Mexico to Brooklyn, there may be aspects of her transition relevant to other types of travel. She quickly makes a new friend, but at times their differ-


ences seem almost overwhelming. A song appears in both Spanish and English on the endpapers to represent some of the girl's feelings about missing her homeland. Alfonso Ruano's watercolouron-paper artwork pulls at the heartstrings. For ages $5^{-10}$.

(C) BEVERLEY BRENNA, RICHARD DIONNE AND THERESA TAVARES, 2021 
The Land Beyond the Wall:

An Immigration Story

Veronika Martenova Charles

A young girl lives on one side of a wall even though there is happiness and colour on the other side. After her parents disappear, and she spends time with her aunt, she travels on a boat to a country where she is free to become an artist. This story is an allegory for


the author's real struggles. In her afterword, Veronika Martenova Charles discusses her childhood behind the Iron Curtain and her journey to Canada, arriving via Pier 21 in Halifax. The delicate watercolour illustrations are highly evocative and full of emotional depths. For ages $5^{-12+}$.

\section{Paint the Town Pink \\ Lori Doody}

This is a delightful story about a flamingo who finds herself in St. John's, Newfoundland. She looks for a flock of her own but doesn't feel at home until people begin to think pink... and their warm welcome pays off. Doody's printmaking background really shines in this colourful book. For ages $3-8$.

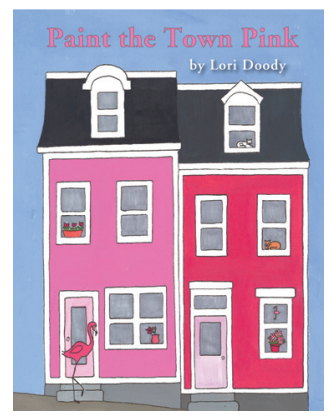

\section{My Beautiful Birds \\ Suzanne Del Rizzo}

This is a story about a young boy's experience in the Syrian civil war. Sami and his family escape a burning city and move into a refugee camp where he misses the pigeons he left behind. Eventually, he recognises that he is still under the same sky, and makes friends with some new birds. The story ends when he reaches

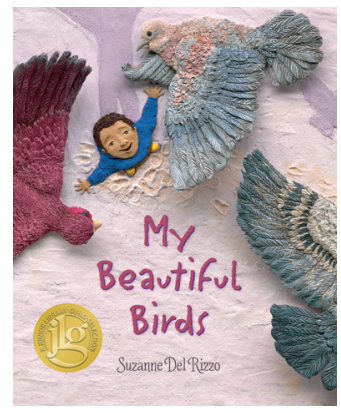
out to another child who is homesick. Suzanne Del Rizzo's illustrations were created with mixed-media, including plasticine, polymer clay, and acrylic. For ages 6-10+. 


\section{Birdsong \\ Julie Flett}

When Katherena moves to her new home far away from the sea, she feels lonely and out of place. A friendship with an elderly neighbour, who shares her love of nature and art, helps Katherena adjust. When the neighbour is dying, Katherena's art creates a poem for her heart. Cree words included in the text are defined in a glossary on the copyright page. Julie Flett, a Cree-Métis author, illustrator, and artist, has created beautifully muted illustrations here in pastel and pencil, composited digitally. For ages $5^{-9}$.

\section{Bitter and Sweet \\ Sandra V. Feder \\ and Kyrsten Brooker}

As Hannah prepares to move with her family to a new town, her grandmother explains how it felt when she left the old country - both bitter and sweet. At first, Hannah feels only bitterness, but a new friend helps her feel at home again. In her author's note, Sandra V. Feder explains

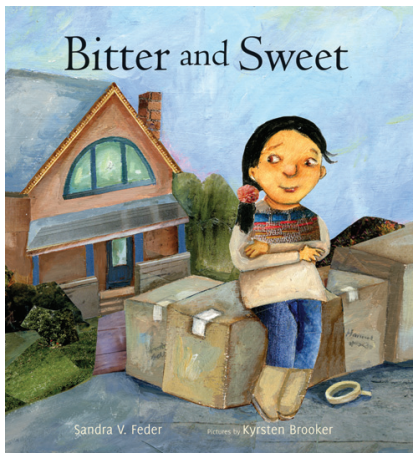
Jewish traditions that contain elements of sweet and bitter. Kyrsten Brooker's illustrations were done in collage and oil paint on gessoed watercolour paper. For ages 4-8.

\section{Mustafa}

\section{Marie-Louise Gay}

This is the story of a little boy who travels a long way with his family to live in a different country. At first he feels invisible, and he has bad dreams about the smoke and fire they left behind. Over time he explores the outdoors and makes a friend, and then Mustafa begins to feel like this new place is home. Mari-Louise Gay's whimsical illustrations present her signature style, grounded in watercolour, pen, and ink. For ages 4-8+.






\section{Malaika's Winter Carnival \\ Nadia L. Hohn \\ and Irene Luxbacher}

Malaika moves away from her grandmother's house to live in Canada with her mother, Mummy's new partner, and a new sister. At first, Malaika hates the cold, the way that people speak differently than what she's used to, and even

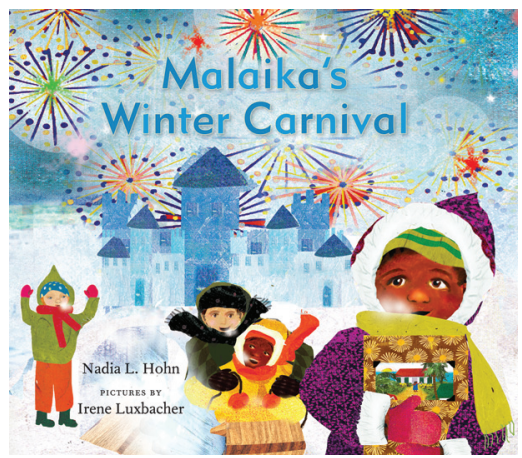
the carnival, where she breaks Adèle's snow castle. Written in a blend of standard English and Caribbean patois, this engaging title has illustrations composed in mixed-media, graphite, and oils on paper. For ages $4-9$.

\section{Ira Crumb Makes a Pretty Good Friend \\ Naseem Hrab \\ and Josh Holinaty}

Ira Crumb is a new kid in town and at first he tries too hard to make a friend. This book, told through speech bubbles with some narration, puts a relatable spin on change and fitting in. For ages $4-8$.

\section{Greetings, Leroy \\ Itah Sadu \\ and Alix Delinois}

Roy is writing a letter back home to his friend in Jamaica. He tells Leroy all about his new life in North America and how different it is from what he's used to. A Bob Marley button given to Roy by a neighbour before he moved features importantly in this warm story about finding a new home while stay-

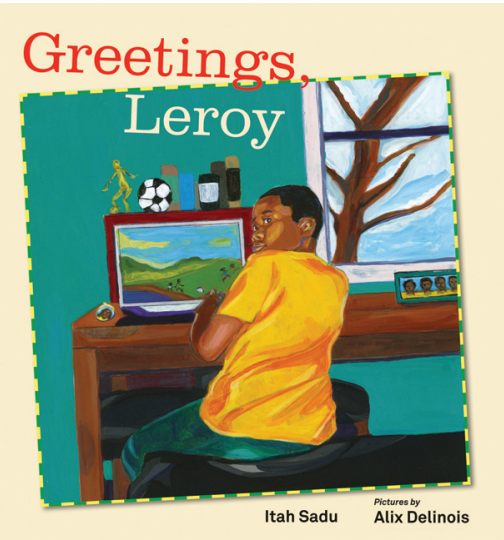
ing proud of where you're from. The bright illustrations by Alix Delinois were created in acrylic and mixed-media. For ages $4-9$. 


\section{Bibliography}

*In the spirit of the recommendations of the Truth and Reconciliation Commission, an asterisk appears beside works created by Indigenous writers or artists.

Amado, Elisa (illustrated by Alfonso Ruano) (2019). My Friend. Toronto, ON: Groundwood Books/House of Anansi Press.

Charles, Veronika Martenova (2017). The Land Beyond the Wall. Halifax, NS: Nimbus Publishing.

Del Rizzo, Suzanne (2017). My Beautiful Birds. Toronto, ON: Pajama Press.

Doody, Lori (2019). Paint the Town Pink. Tors Cove, NL: Running the Goat/Books \& Broadsides.

Feder, Sandra V. (illustrated by Kyrsten Brooker) (2018). Bitter and Sweet. Toronto, ON: Groundwood Books/House of Anansi Press.

*Flett, Julie (2019). Birdsong. Vancouver, BC: Greystone Books.

Gay, Marie-Louise (2018). Mustafa. Toronto, ON: Groundwood Books/House of Anansi Press.

Hohn, Nadia L. (illustrated by Irene Luxbacher) (2017). Malaika's Winter Carnival. Toronto, ON: Groundwood Books/House of Anansi Press.

Hrab, Naseem (illustrated by Josh Holinaty) (2017). Ira Crumb Makes a Pretty Good Friend. Toronto, ON: Owlkids Books.

Sadu, Itah (illustrated by Alix Delinois) (2017). Greetings, Leroy. Toronto, ON: Groundwood Books/House of Anansi Press. 